\title{
Hotel Chains and the Sharing Economy in Global Tourism
}

\author{
Daniela M. Salvioni*
}

\begin{abstract}
The global tourism industry has experienced steady growth in recent years. In this context, the sharing economy has changed the rules of global tourism, developing multi-sided technology platforms for the provision of hospitality with a range comparable to that of major hotel groups.

The sharing economy is an emergent economic-technological phenomenon fostered by developments in ICT, considered both a disruptive innovation and a competitive threat to hotel companies.

Accommodation sharing modifies the traditional short-term rigidity of the location-based hospitality offer, with a positive impact on global tourism as well as a significant change in the competitive conditions of the hotel market.

This paper considers the role of hotel chains in global tourism and the effect on their governance generated by recent developments in accommodation sharing, of which Airbnb is pioneer and leader.
\end{abstract}

Keywords: Hotel Chains; Sharing Economy; Sharing Accommodation; Corporate Governance; Tourism Market; Competitive Strategy

\section{Hotel Chains in Global Markets}

Hotel chains have been subject to growing international development since the Second World War, although the term has more ancient origins.

Indeed, the term 'hotel chain' can be traced back to the 1920s when the individual ownership model gave way to a corporate ownership model as a result of the increasing costs of building, maintaining and operating hotels. The 1950s marked the internationalization of the sector with the aim of achieving critical mass, improving the balance between generating short-term cash flows and expanding accommodation capacity in the long term, attracting new customers and focusing on service innovation.

International hotel chains started developing after World War II, especially in the US, growing substantially in the 1960s and expanding greatly in the subsequent two decades (Johnson \& Vanetti, 2005; Chon \& Cunill, 2006).

Since the 1990s, the gradual lowering of space and time barriers in the circulation of information, goods, capital and people further propelled the growth of international hotel chains with the establishment of large hotel groups.

* Full Professor of Business Administration, University of Brescia (daniela.salvioni@ unibs.it)

Edited by: ISTEI - University of Milan-Bicocca

ISSN: 1593-0319

Salvioni, D. M. (2016). Hotel Chains and the Sharing Economy in Global Tourism, Symphonya. Emerging Issues in Management (symphonya.unimib.it), 1, 31-44. 
Currently, the top ten hotel chains have a large number of hotels across the globe and control $75 \%$ of the biggest hotels.

From the beginning of this decade, the emergence of new markets and the increasing demand for hospitality services has prompted hotel groups to focus on business growth through expanding their market share in the global hotel industry. The global tourism industry is also experiencing steady growth, with international tourist arrivals increasing by $4 \%$ or more every year (Figure 1) (UNWTO 2016).

Figure 1: International Tourist Arrivals (million)

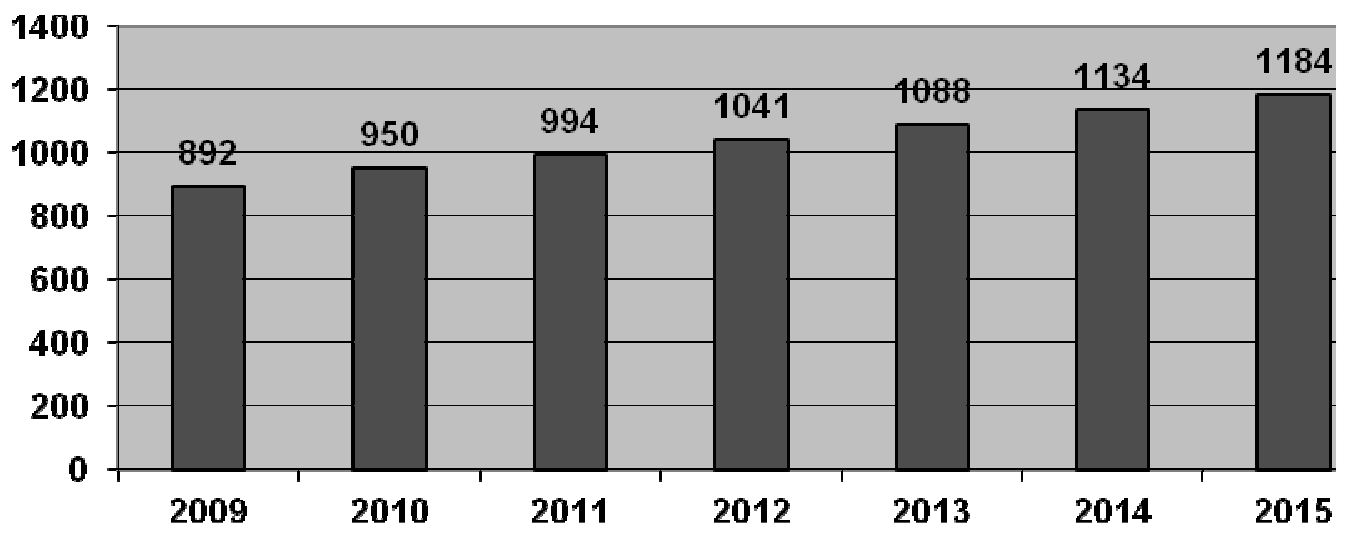

Source: World Tourism Organization UNWTO

The driving forces behind the growth and complexity of global markets have led hotel companies to adopt territorial expansion strategies according to the following models: ownership, leasing, management and franchising. The ownership model, as the term suggests, implies the hotels are owned and operated by an owner who bears all the costs and benefits. The leasing model is similar, except that the hotel owner-operator does not have outright ownership of the hotel but has signed lease agreements. With the management model, hotel owners use other organizations to operate the hotel on their behalf and pay management fees or brand-licensing fees when the hotel operates under a third-party brand. Conversely, franchised hotels are owned and operated by third parties and the owner receives a brand-licensing fee.

More than any other business sector, the current global hotel market is characterized by take-overs, consolidations and strategic alliances (Bleeke \& Ernst, 1991; Osborn \& Hagedoorn, 1997; Contractor \& Lorange, 2002; Canina et al., 2005; Robinson \& Stuart, 2007). In particular, hotel groups employ market-driven management strategies (Brondoni, 2008, 2009) that in recent years have resulted in a marked tendency to:

- $\quad$ increase their speed of adaptation to change through mergers and acquisitions;

- increase structural flexibility by reducing the number of owned hotels and focusing on hotel management and franchising;

- $\quad$ increase their number of brands on the market.

$\square$ Thus, for example, the InterContinental Hotels Group (IHG) - a British multinational, first in the world for number of hotels (2015: 4840) and rooms (in 2015: 710,295) - owns the brands Candlewood 
Suites, Crowne Plaza, Even, Holiday Inn, Holiday Inn Express, Hotel Indigo, Hualuxe, InterContinental and Staybridge Suites. In 2015, of the 4840 IHG hotels, 3934 operate under franchise agreements and 658 are managed by the company but are separately owned. In its 2015 Strategic Report approved by the Board on 22 February 2016, IHG highlights: "We predominantly franchise our brands to, and manage hotels on behalf of, third-party hotel owners; our focus is therefore on building preferred brands and strong revenue delivery systems."

$\square$ Hilton Worldwide - the American hospitality company, second in the world for number of hotels (2015: 4278) and rooms (2015: 708,268) has 13 brands across different market segments (luxury, upper upscale, upscale, upper midscale, timeshare) including Conrad Hotels \& Resorts, Canopy by Hilton, Curio - a collection of unique hotels, each with their own history and character in cities across the globe - Hilton Hotels \& Resorts, DoubleTree by Hilton, Embassy Suites Hotels, Hilton Garden Inn, Hampton Inn, Homewood Suites by Hilton, Home2 Suites by Hilton, Hilton Grand Vacations and Waldorf Astoria Hotels \& Resorts. Many of Hilton's properties are franchised to independent operators and companies, and all franchised hotels are regularly inspected by a "Quality Assurance Team" to enforce the brand standards and consistency.

$\square$ Accor Hotels, a French hotel group part of the CAC 40 index that operates in 94 countries, in December 2014 announced an alliance with Huazhu (China Lodging) to accelerate expansion in China, and in December 2015 announced the acquisition of FRHI Hotels \& Resorts, owner of the Fairmont, Raffles and Swissôtel chains. This transaction will include landmark properties such as the Savoy Hotel in London, the Raffles Hotel in Singapore and the Plaza Hotel in New York. In the 2015 Registration Document and Annual Financial Report, Accor highlights: "In 2015, the Group opened 229 hotels or 36,172 new rooms across the world, enabling it to offer a total of more than half a million rooms to its customers. Franchise agreements and management contracts accounted for $92 \%$ of this development, representing more than two hotel openings every three days and 100 rooms every day, while leased hotels represented $6 \%$ and owned hotels 2\%. Of these openings, $70 \%$ were outside Europe, with $39 \%$ in the Asia-Pacific region, $16 \%$ in the Americas and $15 \%$ in the Mediterranean, Middle East, Africa region”.

$\square$ The American diversified hospitality company Marriott International Inc. has 4117 hotels (as of March 2015) in over 80 countries around the world with 701,899 rooms (as of March 2015). In January 2015, Marriott acquired the Canadian hotel chain Delta Hotels with 40 hotels in Canada and in November 2015 announced the acquisition of Starwood Hotels and Resorts Worldwide. As of 2014, Starwood Hotels and Resorts is the world's seventh largest hotel group with 1161 hotels and 339,243 rooms. If the negotiation is successful, Marriott may become the first worldwide group for capacity. 
As Table 1 shows, from 2009 to 2014 the main worldwide hotel groups have expanded their number of hotels and rooms, indicating the increasing importance of globalisation in this industry.

In the 80s, the principal hotel chains were American and until 2011, the top ten hotel groups had headquarters only in advanced economies ( 8 in the USA, 1 in the UK and 1 in France).

Table 1: Top Ten Hotel Groups in the World 2009-2015

\begin{tabular}{|c|c|c|c|c|c|c|c|c|c|}
\hline \multicolumn{2}{|c|}{ Ranking } & \multirow[t]{2}{*}{ Group } & & \multicolumn{2}{|c|}{ Hotels } & \multicolumn{2}{|c|}{ Rooms } & \multicolumn{2}{|c|}{$\begin{array}{c}\text { Change in room } \\
\text { number }\end{array}$} \\
\hline 2010 & 2009 & & & 2010 & 2009 & 2010 & 2009 & & \\
\hline 1 & 1 & IHG & GB & 4432 & 4186 & 643787 & 619851 & 23936 & $3.9 \%$ \\
\hline 2 & 2 & Wyndham Hotel Group & USA & 7112 & 7043 & 597674 & 592880 & 4794 & $0.8 \%$ \\
\hline 3 & 4 & Hilton Hotels & USA & 3526 & 3259 & 587813 & 544361 & 43452 & $8.0 \%$ \\
\hline 4 & 3 & Marriot International & USA & 3329 & 3088 & 580876 & 545705 & 35171 & $6.4 \%$ \\
\hline 5 & 5 & Accor & FRA & 4111 & 3984 & 492675 & 479069 & 13606 & $2.8 \%$ \\
\hline 6 & 6 & Choice & USA & 6021 & 5827 & 487410 & 472526 & 14884 & $3.1 \%$ \\
\hline 7 & 7 & Best Western & USA & 4048 & 4032 & 308477 & 305387 & 3090 & $1.0 \%$ \\
\hline 8 & 8 & $\begin{array}{l}\text { Starwood Hotel and } \\
\text { Resorts }\end{array}$ & USA & 979 & 942 & 291638 & 284800 & 6838 & $2.4 \%$ \\
\hline 9 & 9 & $\begin{array}{l}\text { Carlson Hospitality } \\
\text { Worldwide }\end{array}$ & USA & 1059 & 1013 & 159756 & 151487 & 8269 & $5.5 \%$ \\
\hline 10 & 10 & Hyatt Hotel Corp. & USA & 399 & 373 & 120031 & 114343 & 5688 & $5.0 \%$ \\
\hline 2012 & 2011 & & & 2012 & 2011 & 2012 & 2011 & & \\
\hline 1 & 1 & IHG & GB & 4480 & 4437 & 658348 & 647161 & 11187 & $1.7 \%$ \\
\hline 2 & 3 & Hilton Worldwide & USA & 3843 & 3689 & 633238 & 605938 & 27300 & $4.5 \%$ \\
\hline 3 & 4 & Marriot International & USA & 3537 & 3446 & 617837 & 602056 & 15781 & $2.6 \%$ \\
\hline 4 & 2 & Wyndham Hotel Group & USA & 7205 & 7207 & 613126 & 612735 & 391 & $0.1 \%$ \\
\hline 5 & 5 & Accor & FRA & 4426 & 4229 & 531714 & 506606 & 25108 & $5.0 \%$ \\
\hline 6 & 6 & $\begin{array}{l}\text { Choice Hotels } \\
\text { International }\end{array}$ & USA & 6203 & 6142 & 502460 & 495145 & 7315 & $1.5 \%$ \\
\hline 7 & 7 & $\begin{array}{l}\text { Starwood Hotel and } \\
\text { Resorts }\end{array}$ & USA & 1077 & 1041 & 315346 & 308700 & 6646 & $2.2 \%$ \\
\hline 8 & 8 & Best Western & USA & 4078 & 4015 & 311598 & 307155 & 4443 & $1.4 \%$ \\
\hline 9 & 12 & Home Inns (+ Motel 168) & CHI & 1426 & 818 & 176562 & 93898 & 82664 & $88 \%$ \\
\hline 10 & 9 & $\begin{array}{l}\text { Carlson Rezidor Hotel } \\
\text { Group }\end{array}$ & USA & 1077 & 1078 & 165802 & 165061 & 741 & $0.4 \%$ \\
\hline 2014 & 2013 & & & 2014 & 2013 & 2014 & 2013 & & \\
\hline 1 & 1 & IHG & GB & 4697 & 4602 & 686873 & 675982 & 10891 & $1.6 \%$ \\
\hline 2 & 2 & Hilton Worldwide & USA & 4115 & 3992 & 678630 & 659917 & 18713 & $2.8 \%$ \\
\hline 3 & 3 & Marriot International & USA & 3783 & 3672 & 653719 & 638793 & 14926 & $2.3 \%$ \\
\hline 4 & 4 & Wyndham Hotel Group & USA & 7485 & 7342 & 645423 & 627437 & 17986 & $2.9 \%$ \\
\hline 5 & 5 & Choice Hotels Int. & USA & 6303 & 6199 & 502663 & 497023 & 5640 & $1.1 \%$ \\
\hline 6 & 6 & Accor & FRA & 3576 & 3515 & 461719 & 450199 & 11520 & $2.6 \%$ \\
\hline 7 & 7 & $\begin{array}{l}\text { Starwood Hotel and } \\
\text { Resorts }\end{array}$ & USA & 1161 & 1121 & 339243 & 328055 & 11188 & $3.4 \%$ \\
\hline 8 & 8 & Best Western & USA & 4046 & 4013 & 314318 & 307305 & 7013 & $2.3 \%$ \\
\hline 9 & 9 & Home Inns & CHI & 2180 & 1772 & 256555 & 214070 & 42485 & $19.8 \%$ \\
\hline 10 & 10 & $\begin{array}{l}\text { Carlson Rezidor Hotel } \\
\text { Group }\end{array}$ & USA & 1079 & 1077 & 168927 & 166245 & 2682 & $1.6 \%$ \\
\hline 2015 & 2014 & & & 2015 & 2014 & 2015 & 2014 & & \\
\hline 1 & 1 & IHG & GB & 4840 & 4697 & 710295 & 686873 & 23422 & $3.4 \%$ \\
\hline 2 & 2 & Hilton Worldwide & USA & 4278 & 4073 & 708268 & 672083 & 36185 & $5.4 \%$ \\
\hline 3 & 3 & Marriot International & USA & 4117 & 3854 & 701899 & 662821 & 39078 & $5.9 \%$ \\
\hline 4 & 4 & Wyndham Hotel Group & USA & 7645 & 7485 & 660826 & 645423 & 15403 & $2.4 \%$ \\
\hline
\end{tabular}




\begin{tabular}{|l|l|l|l|l|l|l|l|l|l|}
\hline 5 & 5 & Choice Hotels Int. & USA & 6376 & 6340 & 504808 & 506058 & -1250 & $-0.2 \%$ \\
\hline 6 & 6 & Accor & FRA & 3717 & 3576 & 482296 & 461719 & 20577 & $4.5 \%$ \\
\hline 7 & 7 & $\begin{array}{l}\text { Starwood Hotel and } \\
\text { Resorts }\end{array}$ & USA & 1207 & 1161 & 346599 & 339243 & 7353 & $3.3 \%$ \\
\hline 8 & 8 & Best Western & USA & 3900 & 4046 & 302144 & 314318 & -12174 & $-3.9 \%$ \\
\hline 9 & 9 & Home Inns & CHI & 2609 & 2180 & 296075 & 256555 & 39520 & $15.4 \%$ \\
\hline 10 & 13 & $\begin{array}{l}\text { Jin Jiang (inc. Louvre } \\
\text { Hotels) }\end{array}$ & CHI & 2208 & 918 & 241910 & 128952 & 112958 & $87.6 \%$ \\
\hline
\end{tabular}

Source: Database MKG Hospitality - May 2010 - May 2012 - June 2014 - March 2015

In 2012, the Chinese group Home Inns doubled its capacity thanks to the takeover of its national competitor Motel 168 and 9th in the world rankings of major hotel groups. Home Inns includes brands such as Home Inn, Yitel and Fairyland Hotel and is the largest hotel chain in China.

In 2015, the acquisition of the French operator Louvre Hotels Group by the Chinese group Jin Jiang elevated the Asian group to 10th place in the global hotel operator ranking and confirms the increased competitiveness of Asian hotel groups.

China's interest in the hotel sector is further corroborated by the pursuit of new acquisitions of existing chains. For example, in March 2016, China's Anbang Insurance Group Co. inked a deal to buy Starwood Hotels \& Resorts Worldwide for $\$ 78$ per share. The agreement was a direct challenge to Marriott International, the American hotel giant that had offered \$ 67.22 per share (at current values) in November. Marriott in five days increased its offer, meaning that if Marriott does lose Starwood to Anbang, it will obtain an extra \$ 68 million on top of the initial \$ 400 million termination fee. The deal, however, has not yet been finalised.

In global markets, the growing interest of emerging economies in the hospitality industry implies challenges for hotel chain governance. Furthermore, hotel groups now face the new competitive threat posed by the accommodation sharing economy.

The sharing economy is an emerging economic-technological phenomenon fostered by developments in ICT (Botsman \& Rogers, 2010; Kaplan \& Haenlein, 2010; Wang \& Zhang, 2012) and increasingly concerns the hospitality industry by challenging traditional services.

Accommodation sharing is an alternative way of providing hospitality services with an explosive growth trend. Hotel chains initially paid little attention to the spread of the sharing economy and only after the rapid growth of platforms such as Airbnb did they recognize the importance of such alternative hospitality service provisions.

\section{Hotel Chains and the Accommodation Sharing Economy}

As noted, a new and significant competitive threat to major hotel chains is accommodation sharing. The development of the internet and the subsequent creation of online platforms have made sharing easier than ever (Belk, 2010, 2014; Botsman \& Rogers, 2010; Eckhard \& Bardhi, 2015).

Many platforms in the sharing economy began their activities in the United States and tourism is one of the sectors that has been most affected. These are new business models that employ the internet and smartphones to match excess capacity in private durables to demand (OECD Secretariat, 2015). 
Sharing economy sites generally have lower costs than the market alternatives and greater operational flexibility. The sharing economy also enables eliminating intermediary inefficiencies, reconfiguring markets by identifying avoidable costs in the incumbents' business model (i.e., certain fixed costs) and quickly adapting supply to demand at no additional cost.

Sharing is now a global phenomenon due to both the expansion of platforms in other countries and the fact that the concept of sharing has caught on around the world. The elimination of barriers to the circulation of information and people has facilitated the globalization of accommodation sharing platforms.

Accommodation sharing or home-sharing is a disruptive innovation even if shortterm rentals are not a new phenomenon. Unlike the traditional model of connecting individuals with hotels, accommodation sharing companies connect individuals with each other (Figure 2), consequently modifying the traditional short-term rigidity of the location-based hospitality offer. This has resulted in a positive effect on global tourism as well as a significant change in the competitive conditions of the global tourism market.

\section{Figure 2: The Sharing Accommodation Model}

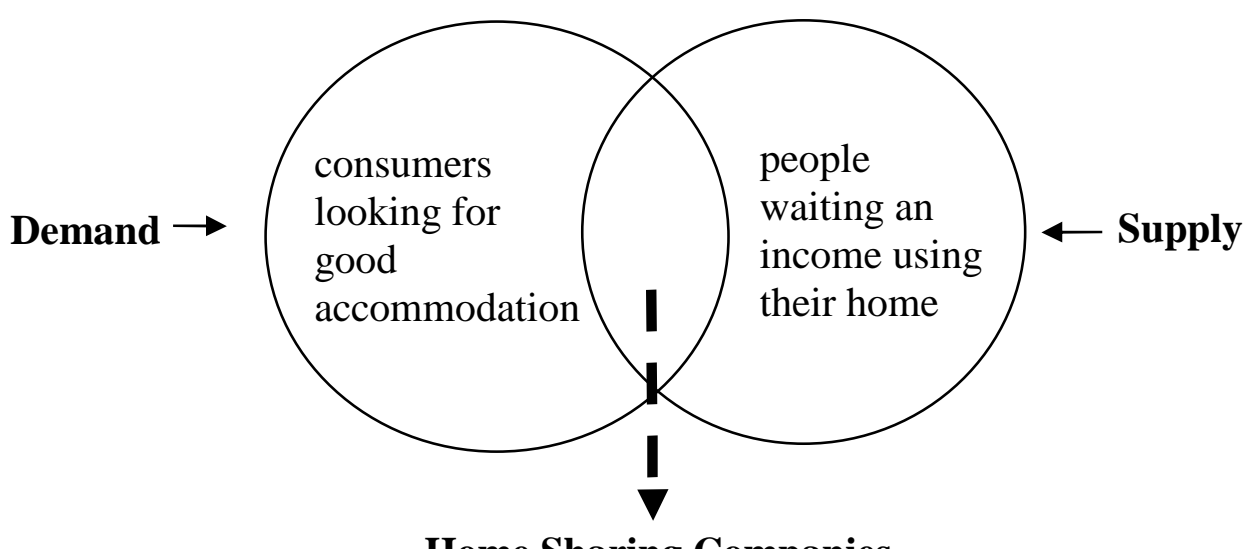

Home Sharing Companies

The peer-to-peer business model and the development of high-speed internet have turned short-term home rentals into a common practice (European Parliament Briefing, 2015). Home-sharing companies, led by Airbnb, have thus given rise to pressing concerns for hotel chains that now face an alternative system of hospitality service provision that has enjoyed explosive growth and offers choices without geographical barriers.

In particular, Airbnb has seen rapid growth from its inception in 2008 and is now the largest peer-to-peer hospitality service worldwide.

In 2015, Airbnb had more than a million rooms available all over the world and more beds than hotel giants such InterContinental, Marriott and Hilton. In June of the same year, investors valued Airbnb at US \$25.5 billion (Figure 3) above Marriott International, Starwood Hotels \& Resorts, Wyndham Hotel Group and AccorHotels. In other words, the largest hotel chains have fewer rooms, much slower growth rates and often much lower valuations compared to Airbnb. 
The impact of the emergence of the room sharing platform Airbnb on the hospitality sector is controversial, but there is no doubt that it constitutes a new competitor for hotels, especially global hotel chains.

The recent development in accommodation sharing, where Airbnb is pioneer and leader, has changed the existing competitive structure of the tourism market, causing a shift in the service user and provider roles. Despite this, hotel chains, at least explicitly, seem reluctant to take substantial action to counter the potential threat from the upstart lodging service.

Accommodation sharing operators, and primarily Airbnb, are now relevant competitive stakeholders, implying that global hotel chains must also take accommodation sharing operators into account in their governance approach and in developing their strategies.

Figure 3: Global Hotel Groups Market Capitalisation versus Airbnb (in billion US dollars)

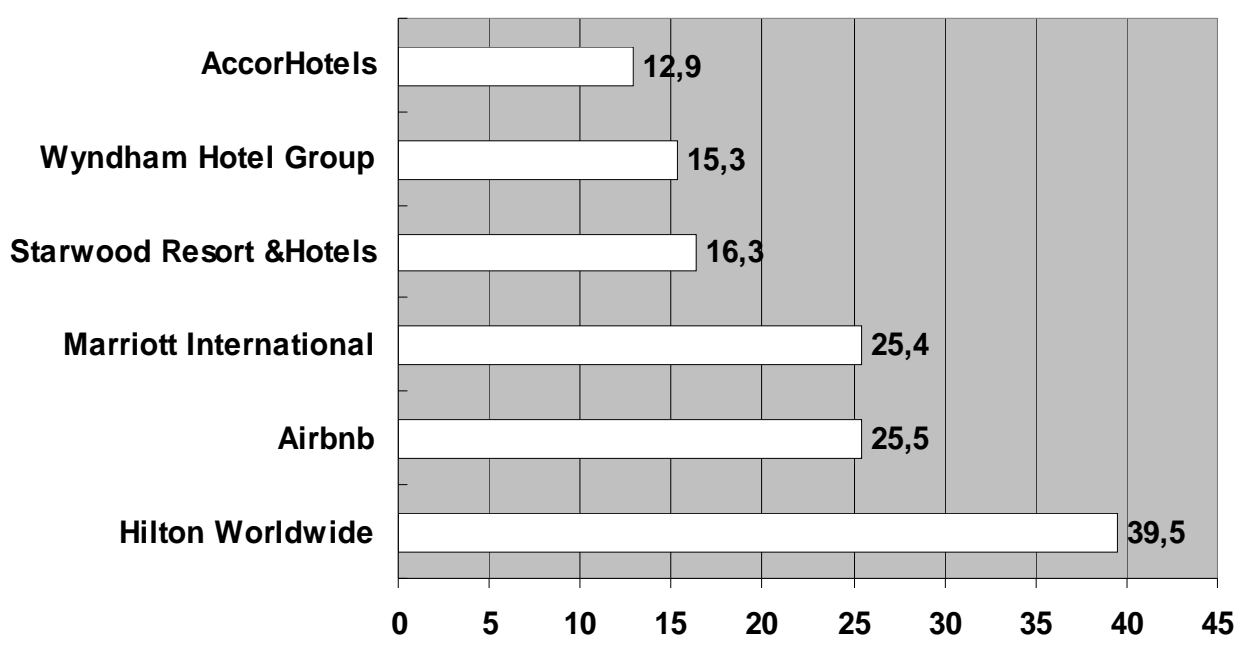

Source: Hospitality On, 2015

A recent Boston University study estimates that Airbnb reduced hotel revenue in the market studied (Austin, United States) by 8-10\% between 2008 and 2014 (Zervas et al., 2015). Although their analysis is confined to a specific geographic area, it also highlights the importance of evaluating Airbnb's phenomenal ascent in defining the business development lines of major hotel groups.

\section{The Rise of Airbnb}

Founded by Brian Chesky, Joe Gebbia and Nathan Blecharczyk in August 2008 in San Francisco (California), Airbnb Inc. was one of the first peer-to-peer services to specialize in home accommodation.

By 2009, Airbnb was already managing a variety of properties including houses and apartments, private rooms, castles, boats, tree houses, Tepees, igloos, private 
islands and other properties. In 2010, 15 people worked at the company's headquarters.

In May 2011, Airbnb acquired the German competitor, Accoleo. This acquisition launched the first international Airbnb office in Hamburg.

In 2012, Airbnb acquired London-based rival CrashPadder, subsequently adding six thousand international listings to its existing inventory and becoming the largest peer-to-peer accommodation website in the United Kingdom.

The growth of Airbnb continued in subsequent years, improving its organizational and IT structure and incentivizing the large-scale conversion of residential units into tourist accommodation.

By August 2015, the Airbnb community spanned 191 countries and 34,000 cities around the world (Airbnb Summer Travel Report, 2015). Airbnb now has nineteen offices in Amsterdam (Netherlands), Barcelona (Spain), Berlin (Germany), Beijing (China), Copenhagen (Denmark), Dublin (Ireland), London (UK), Miami (Florida, USA), Milan (Italy), Moscow (Russia), New Delhi (India), Paris (France), Portland (Oregon, USA), San Francisco (California, USA), São Paulo (Brazil), Seoul (South Korea), Singapore (Republic of Singapore), Sydney (Australia), Tokyo (Japan), and Toronto (Canada).

Airbnb's development has been extremely rapid considering that from 2010 to 2015 summer travel on Airbnb grew 353 times over (Figure 4). Indeed, in the summer of 2010, around 47,000 people took advantage of Airbnb hosts, while in the summer of 2015 Airbnb guests numbered almost 17 million.

Figure 4: Airbnb Summer Travel Growth

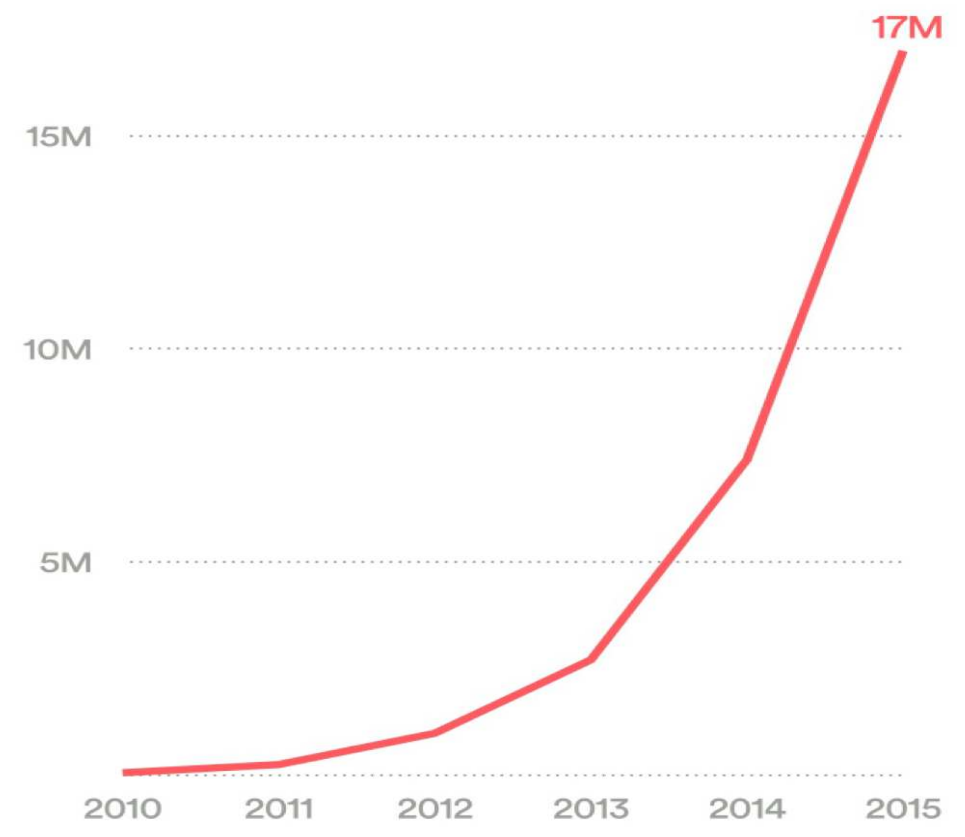

Source: Airbnb Summer Travel Report 2015 
Airbnb's business model is relatively simple and consists of three elements: accommodation providers (hosts), annotated lists and those looking for accommodation (guests).

Both hosts and guests must register with Airbnb, which initially only required a valid email address and phone number to build a unique user profile on the website. Since April 2013, a scan of government-issued ID is also required.

Those using their properties (single rooms, apartments or entire buildings) to earn income list these on the Airbnb platform describing the property's characteristics and the price per night, week, month or the whole season. Site membership is completely free as is the listing. A potential customer who wishes to rent a room, an apartment or a building on Airbnb enters information on the destination and travel dates, and then views a variety of options including the property owner and type, position in the locality, price, availability and other key features.

Guests are required to interact with the owners directly through Airbnb for any questions regarding the property. The owners have $100 \%$ control over reservations of their properties. When a potential guest puts in a reservation request, owners have at least 24 hours to accept or decline it.

Airbnb facilitates online payments from guest to host, security deposits (held until the property is vacated) and cleaning fees. Airbnb's revenue varies from $9 \%$ to $15 \%$ broken down as follows: a commission of $6 \%$ to $12 \%$ of the fee for guests depending on the price of the booking and a commission of $3 \%$ on the amount received by the host. Consequently, the growth of Airbnb revenue is highly conditioned by increasing the number of peer-to-peer exchanges on the platform.

In addition to the Airbnb website and for better functionality of the service, the company offers mobile applications for iOS and Android, and since September 2014, a version for Apple Watch.

Beyond the novelty and pull of new technologies, Airbnb users tend to be motivated by financial and socio-environmental factors. The peer-to-peer platform generally has lower costs than market alternatives, eliminating intermediary inefficiencies and lower overheads compared to those forced to support hotel chains. In particular, Airbnb hosts do not have the high fixed costs typical of hotel operators and can therefore provide their services at a comparatively lower price.

In addition, the rapid increase in accommodation sharing means it is currently relatively unregulated and enjoys certain tax advantages.

\section{Governance of Hotel Chains and New Global Competition}

In global markets, hotel chain governance entails increasing complexity determined by the development of international tourism (UNWTO, 2016), continually evolving consumer needs and the emergence of new competitors.

Particularly since the beginning of this decade, target markets have expanded, the weight of emerging countries at the level of large hotel groups has increased and the sharing economy has rapidly developed as a short-term rental provider. These closely related phenomena demonstrate the increasing revenue potential for all operators in the sector while requiring greater attention to business strategies in view of the critical factors that now determine competitive and social success and the importance of effectively activating stakeholder engagement (Salvioni, 2003; Salvioni \& Astori, 2013). 
The demographic profile of guests continues to evolve and in conjunction with the developments in digital technology these trends drive different accommodation needs and expectations. This is evident across all age groups, particularly among millennials (the generation born in the early 1980s to late 1990s) who are becoming an increasingly important guest cohort (Hjalager, 2013). This cohort is also challenging some of the well-established norms of travel due to having more flexible work arrangements, seeking more personalised and unique experiences and being more open to using the sharing economy to meet their accommodation needs.

Other trends include the blurring of business and leisure travel, with a growing number of professionals adding leisure days onto business trips, and the increasing use of peer-to-peer global platforms (such as Airbnb) by independent (non-branded) hotels to improve the degree of saturation of their accommodation capacity.

The developments in digital technology (Rieple \& Pisano, 2015), the elimination of barriers to the movement of people and information (Brondoni, $2015 \mathrm{~b}$ ), and the change in consumer needs are modifying the competitive landscape of the accommodation industry. Thus, in global markets, hotel chains compete with each other, with independent hotels, with travel intermediaries and companies offering alternative lodging solutions, such as Airbnb.

In particular, the explosive rise of Airbnb since 2009, has forced hotel groups to take a proactive approach, strongly oriented towards stakeholder engagement, building preferred brands and improving the way customer expectations are satisfied. These phenomena are flanked by an increased focus on new information technologies and the emergence of multi-sided technology platforms.

The proactive approach is significantly influenced by the adoption of policies that emphasise the principles of global responsibility, positive and equal interaction with stakeholders and respect of the environment.

Active participation in a more efficient, environmentally oriented and competitive economy has determined vast changes in the complexity of relations between hotel groups and their key stakeholders. Furthermore, the diffusion of knowledge enables the latter to be better informed and to evaluate or compare the offers (Salvioni \& Bosetti, 2014).

Indeed, corporate social responsibility (CSR) emphasizes the role of stakeholder engagement as an essential condition of competitive and social success. Companies recognize the value of interaction with key stakeholders, adopting a broad concept of responsibility that underlines the close interdependence between economic, social and environmental objectives. Such behaviour involves changes in the governance approach according to a business model that focuses greater attention on the shift in customer expectations and the equitable composition of these expectations with those of other stakeholders. Furthermore, increased focus on the environment leads to the juxtaposition of expanding accommodation capacity with direct investments to reduce operating costs and improve the corporate image (for example, investments in renewable energy or for the reduction of water consumption).

Managing stakeholder relationships is an intrinsic component and strategic driver for hospitality companies. This approach is based on a modern interpretation of the link between the long-term success of enterprises and appropriately balancing all stakeholder interests (including those of shareholders, employees, customers, creditors, suppliers and local communities) (Lambin, 2014; Salvioni \& Gennari, 2014; Salvioni \& Gennari, 2016). 
With brands, employees, guests, owners and competitors all around the globe, hotel groups enjoy a rich tapestry of diversity in their business. Wide geographic dispersion and territorial expansion strategies entailing closer relations with thirdparties requires maintaining high and consistent quality standards, training and disseminating a common ethical culture throughout the group.

By acting with integrity, hotel chains positively affirm their and their brand's image and reputation. Doing business responsibly enables building consensus, trust and preferences for hotel brands, operating more effectively and creating long-term value for shareholders and stakeholders.

Brand equity has a primary governance role for hotel chains (Brondoni, 2015 a) and constitutes a key success factor. However, Airbnb has essentially bypassed the brand loyalty and trust that hotel brands have had to build over decades. Similarly, to all other accommodation sharing businesses, Airbnb has focused on flexible market integration typical of e-commerce sites. The comparison of hotel groups and competitors of the sharing economy thus entails a greater focus on investments in information technology.

$\square$ For example, the 2015 IHG Annual Report 2015 states: "Technology is playing an increasingly important role in shaping the travel industry and underpins everything that we do for guests, owners and colleagues around the world. We believe that keeping abreast of trends as they evolve and investing in technology systems will assist us in building brand preference, strengthening our loyalty programme and delivering compelling and engaging digital content across the 'Guest Journey', enabling us to build lifetime relationships with our guests”.

The 2015 Accor Registration Document and Annual Financial Report states: "In October 2014, AccorHotels announced the rollout of an ambitious five-year $€ 225$ million investment plan that will engage the Group in a wide-ranging digital transformation aimed at consolidating its leadership across the guest experience value chain. In June 2015, the value of the plan was increased by $10 \%$ following the launch of the accorhotels.com marketplace. In 2015, €78 million was spent (€5 million in 2014), with an impact as anticipated on the performances of the HotelServices business.

The "Leading Digital Hospitality" plan is based on a holistic response to the challenges of an increasingly digital world, in a market environment shaped by the accelerating pace of technological change, the arrival of new disruptors and rapid changes in guest behavior".

Hilton Worldwide in its 2015 Annual Report asserts, "We depend heavily upon our information technology systems in the conduct of our business. We own and license or otherwise contract for sophisticated technology and systems for property management, procurement, reservations and the operation of the Hilton HHonors customer loyalty program."

Furthermore, after initially underestimating the threat posed by Airbnb, some hotel groups are implementing new investment strategies in rival home-sharing. 
$\square$ Thus, for example, on 29 June 2015, the Financial Times reported: “... Hyatt Hotels was revealed to be among a group of investors to join a \$40m fundraising round for Onefinestay, a six-year-old UK company and upmarket competitor to Airbnb that allows people to sleep in highend locations.

Wyndham Hotels, whose brands include Ramada and Travelodge, has taken a stake in another London-based start up called LoveHomeSwap, a subscription service that allows homeowners to swap their homes, according to two people familiar with the matter....

In April, InterContinental Hotels Group, the world's largest hotels company by number of rooms, announced digital initiatives including a partnership with Stay.com, an Oslo-based group that offers tailored tourist guide".

Technology has indeed changed the competitive landscape in which hotel chains operate with the arrival of new competitors in the accommodation industry and determining new critical success factors. This is turn implies that the governance choices of hotel chains require increasing attention to information technology both as a means of stakeholder engagement and building global platforms to manage guest interactions as a business development alternative in peer-to-peer accommodation.

\section{Bibliography}

Airbnb Summer Travel Report (2015), http://blog.airbnb.com/wp-content/uploads/2015/09/AirbnbSummer-Travel-Report-1.pdf.

Belk, R. (2010), Sharing, Journal of Consumer Research, 36, 5, pp. 715-34.

Belk, R. (2014), You are what you can access: Sharing and collaborative consumption online, Journal of Business Research, 67, 8, pp. 1595-1600.

Bleeke, J., Ernst, D. (1991), The Way to Win Cross-Border Alliances, Harvard Business Review, November-December.

Botsman, R., Rogers, R. (2010), Beyond Zipcar: Collaborative consumption. Harvard Business Review, 88, 10.

Brondoni, S.M., (2008), Market-driven management, competitive space and global networks. Symphonya. Emerging Issue in Management, n. 1, pp. 14-27.

http://dx.doi.org/10.4468/2008.1.02brondoni.

Brondoni, S. M. (2009), Market-Driven Management, Competitive Customer Value and Global Networks, Symphonya. Emerging Issues in Management, n. 1, pp. 8-25.

http://dx.doi.org/10.4468/2009.1.02brondoni

Brondoni, S. M., (2015 a), Global Networks, Outside-In Capabilities and Smart Innovation, Symphonya. Emerging Issues in Management, n. 1, pp. 6-21.

http://dx.doi.org/10.4468/2015.1.02brondoni

Brondoni, S. M., (2015 b), Product Design Management and Global Competition, Symphonya. Emerging Issues in Management, n. 2, pp. 13-24.

http://dx.doi.org/10.4468/2015.2.02brondoni

Canina, L., Enz, C. A., \& Harrison, J. S. (2005), Agglomeration effects and strategic orientations: Evidence from the US lodging industry. Academy of Management Journal, 48(4), pp. 565-581. 
Chon, K.S., Cunill, O.M. (2006), The growth strategies of hotel chains: Best business practices by leading companies, The Haworth Press.

Contractor, F. J., Lorange, P. (2002), The growth of alliances in the knowledge-based economy. International Business Review, 11(4), pp. 485-502.

Eckhard, G. M., Bardhi, F. (2015), The Sharing Economy Isn't About Sharing at All, Harvard Business Review Online, January 28.

European Parliament Briefing (2015), The sharing economy and tourism. Tourist accommodation, http://www.europarl.europa.eu/RegData/etudes/BRIE/2015/568345/EPRS_BRI(2015)568345_EN .pdf

Hjalager, A. M. (2013), 100 Innovations That Transformed Tourism. Journal of Travel Research.

HospitalityOn (2015), Record valuation for Airbnb, http://hospitalityon.com/en/news/2015/06/29/record-valuation-for-airbnb/

Johnson, C., Vanetti, M. (2005), Locational strategies of international hotel chains. Annals of Tourism Research. 32(4), 1077-99.

Kaplan, A. M., Haenlein, M. (2010), Users of the world, unite! The challenges and opportunities of Social Media. Business Horizons, 53, 1, pp. 59-68.

Lambin, J-J. (2014), Rethinking the Market Economy, Symphonya. Emerging Issues in Management, n. 2, pp. $4-15$.

http://dx.doi.org/10.4468/2014.2.02lambin

MKG Hospitality's global ranking (2010), http://www.hospitalitynet.org/news/4045874.html

MKG Hospitality's global ranking (2012), http://hospitalityon.com/en/news/2012/04/11/worldwide-hotel-ranking-2012/

MKG Hospitality's global ranking (2014), www.hotel-online.com/press_releases/release/globalhotel-rankings-the-leaders-grow-stronger-ihg-retains-top-spot

MKG Hospitality's global ranking (2015), http://www.hospitalitynet.org/news/4065792.html

OECD Secretariat (2015), Hearing on Disruptive Innovation. http://www.oecd.org/officialdocuments/publicdisplaydocumentpdf/?cote=DAF/COMP(2015)3\&d ocLanguage $=\mathrm{En}$

Osborn, R., Hagedoorn, J. (1997), The institutionalization and evolutionary dynamics of interorganizational alliances and networks, Academy of Management Journal, Vol 40, pp. 261-278.

Rieple, A., Pisano, P. (2015), Business Models in a New Digital Culture: The Open Long Tail Model, Symphonya. Emerging Issues in Management, n. 2, pp. 75 - 88.

http://dx.doi.org/ 10.4468/2015.2.06pisano.rieple

Robinson, D. T., Stuart, T. E. (2007), Network Effects in the Governance of Strategic Alliances. Journal of Law, Economics, and Organization, 23, pp. 242-73.

Salvioni, D. M. (2003), Corporate Governance and Global Responsibility, Symphonya. Emerging Issues in Management, n. 1, pp. 44-54.

http://dx.doi.org/10.4468/2003.1.05salvioni

Salvioni, D. M., Astori R. (2013), Sustainable development and global responsibility in corporate governance, Symphonya. Emerging Issue in Management, n. 1, pp. 28-52. http://dx.doi.org/10.4468/2013.1.03salvioni.astori.

Salvioni, D. M., Bosetti, L. (2014), Sustainable Development and Corporate Communication in Global Markets, Symphonya. Emerging Issues in Management, n. 1, pp. 32-51. http://dx.doi.org/10.4468/2014.1.03salvioni.bosetti

Salvioni, D. M., Gennari, F. (2014). Corporate governance, sustainability and capital markets orientation, International Journal of Management and Sustainability, vol. 3, p. 469-483

Salvioni, D. M., Gennari, F. (2016), Corporate Governance, Ownership and Sustainability, Corporate Ownership \& Control, Vol. 13, Issue 2, Winter, pp. 604-612.

UNWTO (2016), World Tourism Barometer.

Wang, C., Ahmed, P. (2007), Dynamic capabilities: A review and research agenda. International Journal of Management Review, 9, pp. 31-51. 
Wang, C., Zhang, P. (2012), The Evolution of Social Commerce: The People, Management, Technology, and Information Dimensions, Communications of the Association for Information Systems, 31, pp.105-127.

Zervas, G., Proserpio, D., \& Byers, J. W. (2015), The Rise of the Sharing Economy: Estimating the Impact of Airbnb on the Hotel Industry. Boston University School of Management Research Paper Series. 